\title{
THE HISTORY OF KHILAFIAH IN INDONESIA
}

\author{
Oleh: \\ Wisliy \\ Dosen Prodi Aqidah dan Filsafat Islam UIN Imam Bonjol Padang \\ Email: Wisly@uinib.ac.id
}

\begin{abstract}
:
The appearing Khilafiah in Indonesian Islamic History because of the side opinion of Ulama - Moslem Theologian - in using a nash as be an evidence in distinction of the rule of figh usage. It's always influenced by the time and the condition, for instance among modernists and traditionalists acknowledge al Qur'an and as Sunnah are interpretable; while it's also insisted by the aspect of government's politics as a need such as it's happening until today. This writing uses the method of library research by using historical and content analysis approach.
\end{abstract}

Key word : Khilafiah, Theology, Decision, Politics.

\section{A. Preface}

Difference opinion in Islam appears since the existence of Ijtihad, while it had been found since the time of Prophet Muhammad. So that, although it's still in small amount, but something that must be noted that difference opinion existed in the period of Rasulullah. Only the negative impact that usually appears from the subjective factor can be overcome, because the Prophet, as place of the final complaint, is still life.

After passing away of Prophet, and added by more and more the growth of Islamic area power, the need against ijtihad also increased. The problems of khilafiah, when the Prophet lives, can be overcome by giving justification to all debating groups either by his keep silent or his open manner. When the Prophet was died, it shows up negative impact. The superiority of Ulama's opinion, whom they have authority, always be moved by some people especially by their common followers who don't realize mercy in difference.

To have different opinion in ijtihad is a proper if not be said must be, because Holy Qur'an itself is interpretable one. Even Prophet Muhammad had guaranteed by one reward for whom he is mistaken in performing his ijtihad. But, if the 
wrong was appeared and based on certain motivations out of religious persuasion or because of there is no authority to commit ijtihad, so whoever will agree to say that the mistake is out of Prophet's guarantee with its one reward.

Sayid Baqir Shader, as quoted by Jalaluddin Rahmat, brings forward four kinds of mistake that mujtahid trapped in them. First, sometime the mistake appears because of motivation for reality of justification (tabir al waqi). By this encouragement a fighter for Islam (mujahid) doesn't alters reality that must obey against nash but how to interprete nash is suitable for reality. Second, sometime a fighter for Islam enters nash into nonislamic certain skeleton and then uses it to understand nash (damyu an nash dlimna ithar al khash). Third, may be the fault occurs when mujahid unfastens evidence from situation and condition (tajrid al dalil as syar'iy min dhurufihi wa syuruthihi ). Fourth, because mujahid takes certain attitudes with description that precedes him when he faces to nash (ittikhadz mauqif mu'ayyan musabbaqah tujah an nash) (Jalaluddin Rahmat, 1988: 177-179).

\section{B. Causes Of Appearing Khilafiah Problem}

As had been said in prededing one that with the interpretable character of al-Quran may be the difference of opinion to understand it can't be escaped. It's the same as al-Qur'an, different opinion against Hadits also can be found, even it possibility is bigger then al-Qur'an; because the field that will give speculative assumsion of Hadits is wider then what al-Qur'an gives. Al-Qur'an just giving the possibility of different opinion in its guidance, but for Hadits the different opinion not only in side of its guidance but also its deriving.

To confirm the statement above, Ulama deliver various evidences simultaneously as the cause factors how the different opinion becomes. Of course, if it will be still tolerated, must be cleared either from individual or group subjective motivations. For this case, Dr. Bayanuni had presented four factors that cause the law conclusion distinguishes between mujahid each others:

1. Distinguishing opinion in the case of existing or not a nash, and can or can't a nash is chosen as evidence. This difference is always begun by the geographical condition of a Mujtahid ( expert in Moslem law who interpreters Qur'an and Hadith ) or different assessment against perawi, who narrates or delivers Hadith, or the text of Hadith. From this one then the problem grows, for instance, there is a Mujtahid who receives criticizing of Hadith Mursal and denies it. 
2. The difference in understanding a nash. If the Mujtahid agreed that a nash can be an evidence, so they still possible differ how to understand it. As known that the nash is in Arabic and also can be found in it the word of musytarak, mujmal, hakiki, majazi, and others. All of them born because of the linguistic factor.

3. Distinguishing in jamak and tarjih method. Although the Mujtahid agreed in usage of a nash and also its understanding. Distinguishing opinion is still possible to be if there is another nash openly contradiction each other. In this condition, distinguishing opinion begun from the ways that committed by each Mujtahid either in compromise or in tarjih of both the nash. In this aspect, the factor of understanding gives huge enough impact.

4. Distingushing opinion is because of different rule of ushul fiqh and law resources, such as Hanafi leader of mazhab - doesn't accept mafhum mukhalafah for getting conclusion of law, but a great deal of Ulama - Moslem theologian - had used it. Another example, according to Hanafi ideology, the nash 'am is able to give certain guidance (qathiy) but for a bulk of Ulama the nash 'am just to indicate prediction of dhanniy. It is also in the usage of law resource, Malik (leader of mazhab) considers that good action of Madinah inhabitant can be as law resource, but it's not for the other three leaders of mazhab.( Bayanuni, 1986: 18-21) According to the writer, this the fourth different opinion explicitly had been involved in the second causes; because the rules of ushul al fiqh itself established on inductive reasoning and understanding against nash. It is also committed in difference of the usage law resource, while because of both geographical factor and understanding factor to nash also has big influence.

\section{Khilafiah Problem In Indonesia: Background and Its Impact}

Based on various historical note can be known that the case of khilafiah in Indonesia absolutely differs with what had been considered by Bayanuni above. In certain aspects the appearance case of khilafiah isn't becaused of the impact of distinction in understanding Qur'anic nash, but it had been more in behavior and characteristic against interpretation authority of both resources al- Qur'an and Hadits.

Not only among modernists but also tradisionalists acknowledged that al- Qur'an and as Sunnah are interpretable; futher more tradisionalist is more believing and giving the right 
fully against preceding Moslem theologian in interpretation of the both resources. Accordding to traditionalist whole of Islamic doctrins had been representative one in some writing books of preceding Ulama. By this reason doesn't need again to commit reinterpretation against al- Qur'an and Hadits. More then that, this case is expected a dangerious one because it can bring disinterpretation. ( Howard M. Federspiel, 1970: 47 )

Finally,the thought pattern above resembles a committee, then appears some social groups that obliges taqlid in one side and ijtihad in another one. For those who oblige taqlid take turns that follow mazhab is the peace way in understanding Quranic and Prophet tradition teaching. ( Howard M. Federspiel, 1970: 47 ). Cultus that is more than necessary against the genius of imam and mazhab arouses notion that now the brain of man is not able match what had been performed by the founders of mazhab. Extremely, sometime mazhab is considered as infallible teaching, even never needs more deeply research on the truth.

Based on theory, the thought of someone that standardized by one madzhab, of course can't escape from both external and internal factors which influences it. External factor means that condition of social and culture where the mujtahid lives, and internal factor is the capability of mujtahid's knowledge and intellectual in knowing what revelated by Allah SWT. From here then the meaning of khilafiah grows until distinction of ushul al figh's rule usage, compromising and translation, the usage source of law and others.

Imam Abu Hanifah for instance, a man whom he was born and grown in Kufah - a region that is far from where revelation had been sent down - a place where both Hadits grow and prophet's companions dwell. So that, they have different pattern opinion with Ulama in Hijaz, especially Madinah. According to Imam Abu Hanifah is better to use opinion rather than Hadits that is disturbed its validity. Beside that, in that time Kufah was as central of Islamic civilization where civilization of Persia and Roman had assimilated with Islam. It can be said that the condition will appear a number of more complete problems than in Hijaz. By the reason, although Imam Abu Hanifah lives in the same age with Imam Malik, but both of them have different pattern of opinion, especially in the usage of opinion.

Then, Imam Malik whom he is a big expert in Islamic law where born and grown in Madinah, a place where revelation was sent down and a great deal of companions dwell in. It's a reasonable one that Imam Malik can cet Hadits easier than Abu Hanifah whom he stays in Kufah. It must be noted that facility of transportation and communication in that time can't give ease to information for measurement of distance between Madinah and Kufah. The condition of Madinah's social and 
culture is still a simple one and easily to find Hadits; it's a reasonable one for Imam Malik to own special pattern opinion, and then its mazhab is known and mentioned by Ahli al Hadits.

The same problem also had been performed by Imam Malik. The first, he is tilted by Imam Malik's opinion pattern, but after roaming to Iraq and stayed there for several years to study Fiqh of Abu Hanifah then he tilts against trend of Kufah. In Kufah he delivered fatwa, it means some advices of religious matter that according to fiqh literature is usually mentioned qaul qadim. After that, he moved and stayed in Egypt until the end of his life. In this place, he also gave many advices of religious matter that is usually mentioned by qaul jadid, and sometime it is contrary with his fatwa when he was in Kufah.

It's difference with Imam Abu Hanifah, although Imam Ahmad also ever stays in Iraq, the condition of society and religion aren't alike when Imam Abu Hanifah lives there. In that time the contradiction among trend becomes sharp, even in that time Mu'tazilah's doctrine has influenced Abbasiyah caliphs successfully. His strong hate against Mu'tazilah makes him in textual behavior, to hold nash stronger than rasio. ( Farouq Abu Zaid, 1986: 10-44)

Based on the explanation above, is able to be understood that the establishment of mazhab in the growth of Islam is a reasoble one. Mazhab is just establishment system of someone's opinion pattern that bears as reflexion of social and culture condition and geographic one that covers in understanding what had been revelated by Allah. But something that is unreasonable one, if the mazhab is expacted a truth absolutely as the absolute truth of revelation itself. So that, mazhab is not only fulled by relative values, but it also can be false.

The thought that is fastened totally to men in difference of situation and social condition, it is the same with a man who force he himself to live in suitable with someone's need. If a person who had been followed and lived some centuries ago, it is the same with returns the condition of today to be a suitable one with the last condition.

It is a mistaken one when a person decides a law without considerance of opinion pattern which is committed by last mujtahid. Mazhab which its growth can be found in Kitab Kuning reference is as an important aspect in deciding a law and keeps it from the lost of its nowadays context. At above has been mentioned that opinion pattern of someone can't be escaped from the condition of social and culture that covers it. It means, if in determining of law which is leaded by some preceding mujtahid, it is the same with to study al-Qur'an and As Sunnah which had been scoured by the process of history. By this way will be known how far the condition of space and time had influenced mujtahid. 
At early of $20^{\text {th }}$ century, in Indonesia, this mazhab problem always appears in debating forums among traditionalists and modernists. The end of debate is always followed by accusing each other in emotional expressions. The usage of opinion by modernist has become character and at other side is be as accusation by traditionalist to claim that they went out from stripe of Ahli Sunnah Wal Jama'ah, the follower of Mu'tazilah, Wahabi and others. (Howaard M. Federspiel, 1970: 48).

To response accusation of traditionalist, as response of modernist, is the same as its quality with traditionalist. Modernists always said that the effort committed by traditionalist in fact doesn't describe the deep concern against religion, but just how to maintain quo status and need of individual and group with colonial government. ( Howard M. Federspiel, 1970: 48 )

At Java, the sighting to maintain mazhab appears from group of Nahdhatul Ulama ( NU ) and Persyarikatan Ulama ( Deliar Noor, 1985: $80 \quad-84 \quad$ ). Although Persyarikatan Ulama includes loyal mazhab, but the relation which built by it with some modern organizations gives it ability to implement teaching methods which usually used in some modern organizations. Even, its relation with modern organizations is often performed more than what had been committed with traditional organizations. K.H Abdul Halim, as founder and a leader of Persyarikatan Ulama, is too active in Syarikat Islam since 1918 until 1923 ( Deliar Noor, 1985: 84 ). So that, although Persyarikatan Ulama includes a group which maintains mazhab, but its posture more tolerant than $\mathrm{NU}$ and PERTI.

Different opinion among social group is not only begun from ijtihad and taqlid problems, but also from demand of Islamic egalitarianism. The problem of taqbil and kafaah, for instance, had built bad relation between Jami'at Khairiyah and al- Irsyad. The group of sayyid- Arab that usually enjoy more honour and treatment than Moslem community, their status is to be threatened when non group of sayyid- Arab get achievement in both science and matter. The Arab group non- sayyid bravely to ask on the high status of sayyid, namely when Colonial Government appointed a new Arab non- sayyid as a chief of Arab group that is mentioned Arab Captain in one place at Jakarta. Gradually Arab group non- sayyid filt that their status and is the same with the group of sayyid- Arab. ( Deliar Noor, 1985: 77 )

An another happening that increases straining relation between the group of sayyid and non- sayyid also happened in Jakarta. One day an Arab Captain non- sayyid didn't kiss hand ( taqbil ) of a sayyid in a meeting. This simple even made some sayyid offened because their status doesn't have value in the eyes of Arab nonsayyid. ( Deliar Noor, 1985: 78 ) 
Controversy between Jami'at Khairiyah and al- Irsyad basically is a quarrel between a group of democrat in one side and a group of aristocrat in another side. Although begun by simple cases, but the quarrel gave political impact. For instance, in early years of it, press of Jami'at Khoiriyah suggested to Colonial Government to take action against al- Irsyad that accused as the followers of Bolshevik. The press also claimed al- Irsyad because it doesn't support Syarif Husin in Mekkah, that got support from British Government as new caliph. Good relation of the Manasib group in Hadramaut with British government and the group of sayyid which combined in Jami'at Khoiriyyah is guessed hardly as the cause factor then why the people of al- Irsyad had difficulty to get passport to visit Hadramaut. ( Deliar Noor, 1985: 78 )

Some years before conflict at Java, exactly at West Sumatera - at the early of $19^{\text {th }}$ century - had happened great conflict. This conflict is caused by the condition of deed or good work of traditional people had deviated from the truth of religion. In that time 1803, three persons of Haji: Haji Miskin, Haji Sumanik, and Haji Piubang just coming from Mekkah. The condition of social- culture and religion had become more broken down, call their heart of hearts to tidy it up. The campaign opposes custom which helped by some Ulama had been committed in some places. To see movement which done by Paderi people, so custom people also takes part. The fight occurs continually until its climax when battle happens in Lawas town. Under guidance of Datuk Bandaro, Paderi people gets strong position. ( Karel A. Steenbrink, 1984: 32 )

The conflict between Adat people and Paderi people happens continuously. At 1930, the conflict became greater and greater because of intervention of colonial side. Finally, by support of Dutch - people of Paderi - can be conquered. Some of their leaders had been catched and surrendered to Dutch. Both Tuanku nan Cerdik and Imam Bonjol surrender at 1833 and 1834 respectively. ( Karel A. Steenbrink, 1984: 33 )

There is a notion that Paderi war happened because of influence of Wahabism which brought by some Haji after returning from Mekkah. For this opinion, Schreka, as noted by Karel Steenbrink, to oppose it by bring forward several reasons that people of Paderi don't oppose to visit a sacred place- grave - as Wahabi. Beside that, people of Paderi with their figure, Jalaluddin Rahmat, honours strongly agendas such as Maulid Nabi which performed gloriously. ( Karel A. Steenbrink, 1984: 35 ). But, in problems of fiqh, Jalaluddin goes out bravely from mazhab Syafi'i. According to mazhab Syafi'I, the validity of Jum'at prayer, requires at less 40 persons of man; but Jalaluddin establishes Jum'at prayer just with 12 persons. ( Karel A. Steenbrink, 1984: 40 ) 
Building and preparation of personal for future had performed by people of Paderi. Even, the rich people of Paderi, their children study not only in own domestic place but also sent to Mekkah, that considered as the central of ideal religious treaching in that time. To see the progress of religious education that developed by modernists, its note bene is people of Paderi, so people of custom also attempts to emulate it. Syeikh Abbas, for instance, substituted Surau teaching system with Madrasah. ( Delia Noor, 1985: 214 )

In the early $20^{\text {th }}$ century opinion distinction between Modernists and people of custom s not only on fighting cock, eating betel vine leaf, and others as happened in the early $19^{\text {th }}$ century, but begun from the case of ijtihad, taqlid, madzhab and the other cases of khilafiah furu'iyyah. Like its case in Java, in West Sumatera, at last the loyal followers of madzhab also enter an association that mentioned Ittihad al-Ulama Minangkabau, then becomes PERTI ( Deliar Noor, 1985: 214 ). Nowadays, the opinion distinction isn't on the traditional cases but more than that on the difference of method in performing of acculturation.

In committing the process of this acculturation, seems eather in West Sumatera or in Java has many similarity. One side wants to be happened fastly but another one wants to be happened with evolution. To support the evolution stages, traditional people emulates it with very flexible doctrinal offer.It is different with Modernists, offer which brought forward is always anti thesis of traditional people. Slogan " return and al- Hadits " is always carried the voice without paying attention historical factors. Its consequence, the doctrine developed is always not sociological, rigid, and easily claims bid'ah.

Finally, doctrinal flexible attitude which offered by traditional people broadens to field of political culture. This one can be seen when NU and PERTI appear as political party in national stage. The doctrinal flexible character which owned by traditional people gave impression as accommodating and there is no point of view. For instance, when faces PKI, there is distinguishing that strikes the eyes among NU and Masyumi. Because of it, many leaders of NU that accused as " Ulama Nasakom ", includes K.H Abdul Wahab whom he was a leader of Syuriah NU in that time. ( K.H. Saefuddin, K.H. Abdul Wahab Hasbullah, tt: 76 )

The decisions of ijtihadiyah on political case always confuses. It's hard to be valued on what is the case in facing PKI, NU's attitude can be said as tabrirul waqi'. In fact, history witnessed that $\mathrm{NU}$ is one of political party which refuses to open diplomatic relation between Government Republic of Indonesia and Soviet Union in 1953. ( K.H Saefuddin, K.H. Abdul Wahab Hasbullah, tt: 76 ). May be this attitude can be considered is not logic because it's not suitable with 
politic- Bebas Aktif, a political attitude of Indonesian foreign affairs which is not tied by a certain ideology and to participate in the development of world peace. Really, this case indicates about character of NU which then considered opportunist; but at less to remind Government about the peril of communist in Indonesia.

\section{Conclusion}

The analysis above gives description that the basic distinction of opinion among Moslem in Indonesia can be distinguished in some forms :

1. Distiction of opinion because of difference of attitude on reinterptretation authority against

\section{REFERENCES}

A.Seenbrink, Karel, 1984, Beberapa Aspek Tentang Islam di Indonesia Pada Abad ke 19, Bulan Bintang, Jakarta

Azra, Azyumardi, 2003, Surau: Pendidikan Islam Tradisional Dalam

Transisi dan Modernisasi, Jakarta:

Logos Wacana Ilmu

Abu Zaid, Farouq, Hukum Islam Antara Tradisionalis dan Modernis, 1986, Terjemahan (P3M), Jakarta
Alqur'an and Hadits then has appeared group of mazhab followers in one side and not tied up group against mazhab in another one.

2. Distiction of opinion that caused by egalitarianism teaching claim in Islam.

3. Appearance of opinion in Islam is becaused of the consequence of method distinction in acculturation process.

4. The doctrinal flexibility attitude which offered by group of mazhab gaves decision and political thought.

Abdullah, Taufik, 1986, Sejarah Lokal di Indonesia, Yogyakarta, UGM Press

Bayanuni, Memahami Hakekat Hukum Islam, 1986, (terj) Pustaka Azet, Jakarta

Glasse, Cyril, 1999, Ensiklopedi Islam, Raja Grafindo Persada: Jakarta Hasbullah , K.H. Abdulwahab, Bapak dan Pendiri Nahdatul Ulama, tt., Yamunu, Jakarta

Jameelah, maryam, 1981, Islam \& Modernisme (translation), Usaha Nasional, Surabaya- Indonesia 
Noor, Deliar, 1985, Gerakan Modern Waddy, Charis, 1974, The Muslim

Islam di Indonesia: 1900 - 1042.

LP3ES, Jakarta

Soltau, Roger F. 1981, “ An

Introduction Of Politics", London:

Longmas
Mind, London: Longman Group

Ltd 